\title{
Effects of Fermented Rice Wine by Using Mycelium of Phellinus linteus on the Expression of Inflammation-Related Proteins in Human Hepatoma Cells and Rat Liver
}

\author{
Seung-Min Ahn, Jun-Hyuk Lee, Yung-Hyun Choi ${ }^{1}$, Yong-Tae Lee ${ }^{2}$, Kyung-Tae Chung ${ }^{3}$, Young-Kee \\ Jeong $^{3}$, Un-Bock Jo ${ }^{4}$ and Byung-Tae Choi ${ }^{*}$ \\ Departments of Anatomy, ${ }^{1}$ Biochemistry and ${ }^{2}$ Physiology, College of Oriental Medicine, ${ }^{3}$ Department of Life Science and \\ Biotechnology, College of Natural Science, Dong-Eui University, Busan 614-052, ${ }^{4}$ Department of Biology Education, College of \\ Education, Pusan National University, Busan 609-735, Republic of Korea
}

Received November 24, 2005 / Accepted January 18, 2006

\begin{abstract}
We have recently discovered that mycelium of Phellinus linteus, popular medical mushrooms in Korea, possess alcohol dehydrogenase and produce alcohol. In the present study, it was examined that the effect of fermented rice wine made by using mycelium of P. linteus (FLMP) on the expression of inflammation-related proteins in both $\mathrm{HepG}_{2}$ cells and rats. To examine the effect of FLMP on the morphology and expression of inflammatory proteins in $\mathrm{HepG}_{2}$ cells, the cells were incubated with ethanol, and FLMP for 24 hours, and then analyzed by microscopic observation and Western blot and reverse transcription polymerase chain reaction (RT-PCR). While ethanol induced the morphological change accompanied with cell debris formation and scattering on $\mathrm{HepG}_{2}$ cells, FLMP had no effect. The results of Western blot and RT-PCR analyses showed that the level of inducible nitric oxide synthase (iNOS), cyclooxygenase (COX)-1 and COX-2 was induced by ethanol, however, FLMP inhibited the expression of these proteins and its mRNAs. In the animal model, the value of glutamate ox aloacetate transaminase and glutamate pyruvate transaminase was significantly increased by administration with ethanol. But the group administrated with FLMP showed lower levels on the changes of these markers compared with ethanol-administrated group. Besides, the results of Western blot and RT-PCR analyses showed that the expression of inflammatory proteins such as iNOS, COX-1 and COX-2 was not affected by FLMP administration in rat liver. About histopathological and immunohistochemical observations, inflammatory loci were markedly decreased in the FLMP-administrated rat compared to ethanol-administrated rats and showed weaker COX-2 and iNOS immunoreactions. These results suggested that FLMP showed slight changes on the inflammatory proteins expression compared to ethanol and FLMP may be used as a functional alcoholic beverage.
\end{abstract}

Key words - Phellinus linteus, wine, inflammation, liver

The Phellinus linteus, commonly referred to as Sangwhang in Korea, is well known as one of the most popular medical mushrooms due to its high anti-tumor and immunostimulating activities[6,11]. Aqueous extract from the fruiting body or mycelia of $P$. linteus has been reported to produce anti-tumor, anti-angiogenic, anti-mutagenic and immunomodulatory activities in vivo and vitro[3].

Despite such great medical value, $P$. linteus is restricted to use by reason of it being extremely rare to find in the nature and it's high price. During mass-culture of mycelia of this fungus, we have discovered that mycelium of P.linteus possesses some alcohol dehydrogenases and pro-

\footnotetext{
*Corresponding author

Tel : +82-51-850-8653, Fax : +82-51-853-4036

E-mail : choibt@deu.ac.kr
}

duces alcohol. Most alcoholic beverages are made by the fermentation process involving the action of various yeasts [13]. The fermented rice wine is made by using mycelium of $P$. linteus (FLMP) is the first alcoholic beverage without alcoholic fermentation by yeast or any kind of microorganism. Furthermore, if the FLMP is beneficial as P. linteus, this rice wine may be a new type of healthy functional rice wine.

However, all kinds of alcoholic beverages have an injurious effect on the function of the liver and other organs. Thus it is necessary to confirm the effect of FLMP on the inflammatory proteins and liver function markers. The present study was designed to examine the effects of FLMP on the expression of inflammation-related proteins and the change of functional markers in human hepatocarcinoma cells and rat livers. 


\section{Materials and Methods}

\section{Production of FLMP}

To increase ethyl alcohol production the rice-based medium was used, and $P$. linteus was co-cultured with Aspergillus oryzae. First, A. oryzae was aseptically inoculated on $1.2 \mathrm{~kg}$ of autoclaved rice. When the spawned rice had been fully colonized with $A$, oryzae, $3 \mathrm{~kg}$ of autoclaved rice and $90 \mathrm{~g}$ (wet weight) of $P$. linteus mycelia were mixed all together in 5 liters of autoclaved water. Incubation was done for 11 days at $25^{\circ} \mathrm{C}$ without shaking. Each $1.5 \mathrm{~kg}$ of autoclaved rice was additionally added at $24 \mathrm{~h}$ and at 72 $\mathrm{h}$ of the incubation period. The FLMP has $14 \%$ alcoholic concentration.

\section{Antibodies and chemicals}

Antibodies against cyclooxygenase (COX)-1, COX-2 and inducible nitric oxide synthase (iNOS) and secondary horseradish peroxidase-conjugated rabbit immunoglobulin $G$ antibodies were obtained from Santa Cruz Biotechnology (CA, USA). All other chemicals were obtained from Sigma (MO, USA).

\section{Cell culture and treatment}

$\mathrm{HepG}_{2}$ cells were obtained from Korean Cell Line Bank (Seoul, Korea) and were grown in DMEM (Dulbecco's Modified Eagle Medium, GIBCO BRL, NY, USA) supplemented with $10 \%$ fetal bovine serum (GIBCO BRL) and 1\% penicillin-streptomycin (GIBCO BRL). $\mathrm{HepG}_{2}$ cells have been widely employed to analyze in vitro alcoholic disease model systems. The cells were cultured at $37^{\circ} \mathrm{C}$ in a $5 \%$ $\mathrm{CO}_{2}$ atmosphere. Cells were seeded and stabilized for $24 \mathrm{~h}$ and then, treated with a fresh medium containing $14 \%$ ethanol or FLMP for $24 \mathrm{~h}$.

\section{Ethanol and FLMP administration}

Male Sprague-Dawley rats, weighing about $120 \mathrm{~g}$ on average, were obtained from Hyochang Science $\mathrm{Co}$. in Korea. Rats were housed under conditions of $22^{\circ} \mathrm{C}$ and 12 $h$ dark and light cycle, were fed a commercial diet, and allowed tap water ad libitum starting 2 weeks before and throughout the study. Rats were administrated orally $5 \mathrm{ml}$ of $14 \%$ ethanol, FLMP and PBS twice a day for 10 days.

\section{SDS-PAGE and western blot analysis}

Cells were washed in a cold phosphate-buffered saline and lysed in lysis buffer $(40 \mathrm{mM}$ Tris- $\mathrm{Cl} \mathrm{pH} 8.0,120 \mathrm{mM}$
$\mathrm{NaCl}, 0.1 \% \mathrm{NP}-40,0.1 \mathrm{mM}$ sodium orthovanadate, $2 \mu \mathrm{g} / \mathrm{ml}$ leupeptin and $100 \mu \mathrm{g} / \mathrm{ml}$ phenyl methylsulfonyl fluoride) at $4^{\circ} \mathrm{C}$ for $30 \mathrm{~min}$. The lysates were centrifuged at 14,000 rpm for $30 \mathrm{~min}$ at $4^{\circ} \mathrm{C}$, and the supernatants were served as whole cell protein extracts. Rat livers were washed in cold HEPES buffer, and homogenized in 9 volumes of potassium HEPES buffer containing $0.5 \%$ Triton X-100, $1 \mathrm{mM}$ DTT, $5 \mathrm{mM}$ sodium orthovanadate, $10 \mathrm{\mu g} / \mathrm{ml}$ aprotinin, 10 $\mu \mathrm{g} / \mathrm{ml}$ leupeptin and $10 \mathrm{mM}$ phenyl methylsulfonly fluoride. The homogenates were centrifuged at $14,000 \mathrm{rpm}$ for 30 $\min$ at $4{ }^{\circ} \mathrm{C}$ and the supernatants served as liver protein extracts. Equal amounts of proteins were separated by $8-12 \%$ SDS-PAGE. The resulting gels were transferred to immobilon-P transfer membranes (Millipore, Bedford, MA, USA). For Western blotting, the membranes were in cubated with the specific first antibodies for $2 \mathrm{~h}$ at room temperature, and then the blots were incubated with horseradish peroxidase-conjugated secondary antibody. The antibody-specific proteins were visualized by the enhanced chemiluminescence detection system according to the recommended procedure (Amersham, Arlington Heights, IL, USA).

\section{Reverse transcription-polymerase chain reaction (RT-PCR)}

For mRNA analysis, cells and rat livers were washed in cold phosphate-buffered saline and homogenized in TRIzol reagent (Invitrogen) following the manufacturer's manuals. mRNA levels were determined by RT-PCR using the GeneAmp RNA-PCR kit (Perkin Elmer) with 50-100 ng of poly $\mathrm{A}^{+}$RNA and specific primers as previously described [1]. $10 \mu \mathrm{l}$ of the reaction products were subjected to electrophoresis in 1\% agarose gel and visualized by ethidium bromide $(\mathrm{EtBr})$ staining.

\section{Serum analysis}

For the serum analysis, the blood was collected from the heart and immediately centrifuged at 3,000 rpm for $25 \mathrm{~min}$ and the plasma was stored at $-20^{\circ} \mathrm{C}$ for later analysis. Levels of serum glutamate oxaloacetate transaminase (GOT) and glutamate pyruvate transaminase (GPT) were determined by the Cobas Mira (Roche, Switzerland).

\section{Histopathology and immunohistochemistry}

The livers were fixed in $4 \%$ paraformaldehyde in PBS for $18 \mathrm{~h}$ and dehydrated in a graded ethanol series. After embedment in paraffin, serial $5 \mu \mathrm{m}$ thick sections were prepared. For histopathological examinations, hematox- 
ylin-eosin stain and periodic acid Schiff's (PAS) reaction were used. After deparaffinized in $58^{\circ} \mathrm{C}$ xylene, the sections were exposed to $0.3 \%$ methanolic hydrogen peroxide for $30 \mathrm{~min}$, and washed with PBS. Tissues were then treated with goat normal serum at room temperature for 30 min followed by treatment with anti-iNOS, COX-1 and COX-2 diluted for $1: 500$ in moisture chamber at $4^{\circ} \mathrm{C}$ for 16 h. After being washed by PBS, tissues were incubated with the secondary antisera, biotinylated anti-rabbit IgG for 30 min and washed with PBS. These sections were further incubated in avidin-biotin-peroxidase complex kit (Vector Lab. CA, USA) at room temperature for $1 \mathrm{~h}$. Diaminobenzidine substrate kit for peroxidase (Vector Lab. CA, USA) was applied. For the controls, treatment with primary and secondary antibodies was omitted.

\section{Results}

Effect of FLMP on the morphology of HepG 2 cells It was examined the effects of FLMP compared with ethanol on the morphology of liver cell. $\mathrm{HepG}_{2}$ cells were treated with ethanol or FLMP including $0.28 \%, 0.56 \%$ and $1.4 \%$ of alcoholic concentration for $24 \mathrm{~h}$. As shown in Fig. 1 , ethanol induced morphological change including scattering and cell debris formation, while the cells treated with FLMP had no change similar to the control. The result suggests that FLMP have some components which are able to protect cellular morphology or structure from its own alcohol.

\section{Effect of FLMP on the expression of inflammation- related proteins in $\mathrm{HepG}_{2}$ cells}

To investigate the effect of FLMP on the expression of inflammation-related proteins in $\mathrm{HepG}_{2}$ cells, the cells were treated with $0.28 \%$ of alcoholic concentration of ethanol and FLMP for $24 \mathrm{~h}$. As shown in Fig. 2A, expression of COX-1 and COX-2 was induced in $\mathrm{HepG}_{2}$ cells treated ethanol than FLMP. Also, iNOS expressions were strongly induced in $\mathrm{HepG}_{2}$ cells treated ethanol than FLMP. This alleviative effect of FLMP on the protein expression was confirmed by RT-PCR analysis (Fig. 2B). The results indicated that FLMP lowered the induction of inflammation more than ethanol through decreasing the inflammatory
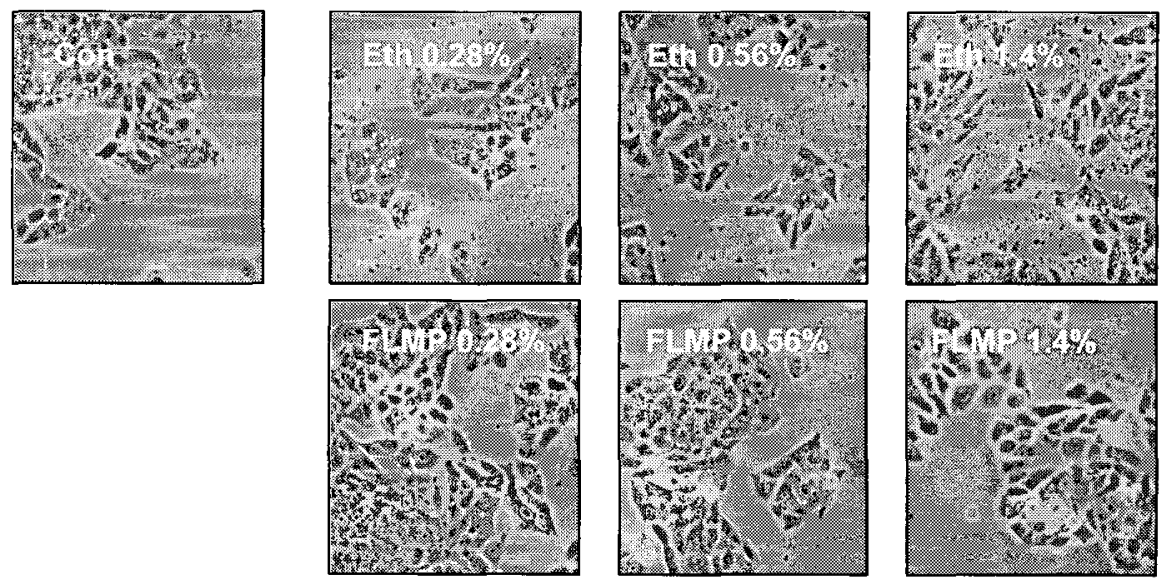

Fig. 1. Morphological changes in $\mathrm{HepG}_{2}$ cells following incubation with ethanol and FLMP. Cells were treated with ethanol and FLMP of various alcoholic concentrations for $24 \mathrm{~h}(\times 200)$.

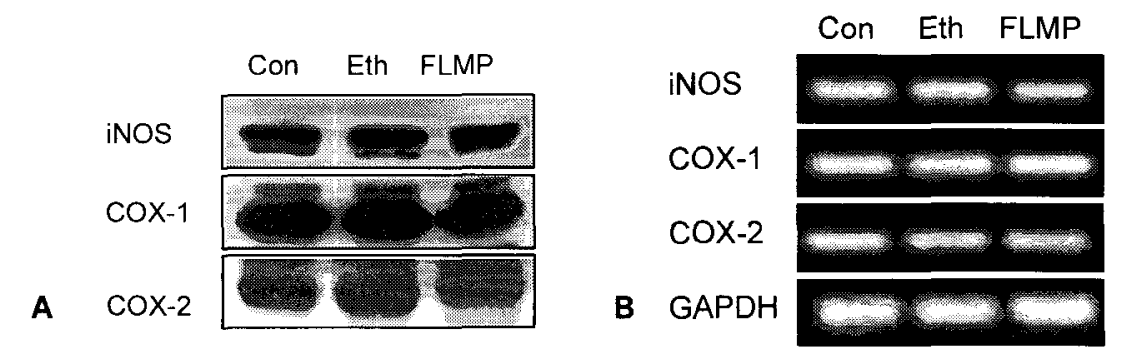

Fig. 2. Effects of ethanol and FLMP on the expression of inflammation-related proteins (A) and mRNAs (B). HepG $\mathrm{H}_{2}$ cells were incubated with ethanol and FLMP $(0.28 \%$ alcohol each $)$ for $24 \mathrm{~h}$. The expression levels of iNOS, COX-1 and COX-2 protein and mRNA were examined by Western blot and RT-PCR as detailed in Materials and Methods. 
protein expression.

\section{Effect of FLMP on the liver function in rats}

In the results of in vitro experiment, ethanol could induce morphological change and inflammation in $\mathrm{HepG}_{2}$ cells, however, FLMP showed little marked effects. Therefore, the effect of FLMP on the liver function was examined in the animal model. Rats were administrated orally $5 \mathrm{ml}$ of ethanol, FLMP or PBS twice a day for 10 days. After treatment, the markers for liver function including serum GOT and GPT were examined. As shown in Fig. 3, the level of GOT was increased in the ethanol-administrated group compared with control, but there was no significant changes. However, GPT level was significantly increased in ethanol-administrated group compared with control and this level also markedly decreased in the FLMP-administrated group compared with the ethanoltreated group.

\section{Effect of FLMP on the expression of inflammation-} related proteins in the rat liver

Fig. 3 suggests that ethanol has injurious effects on the liver function markers relating to inflammation in the liver. Then inflammation-related proteins in the rat liver administrated with ethanol were examined. As shown in Fig. 4A, iNOS, COX-1 and COX-2 protein was increased in the rats administrated with ethanol, but these proteins, especially iNOS, were reduced in the rats administrated with FLMP. To confirm these results, RT-PCR analysis was performed as shown in Fig. 4B.

Histopathological and immunohistochemical observation of rat liver

Inflammatory loci with stromatic changes including

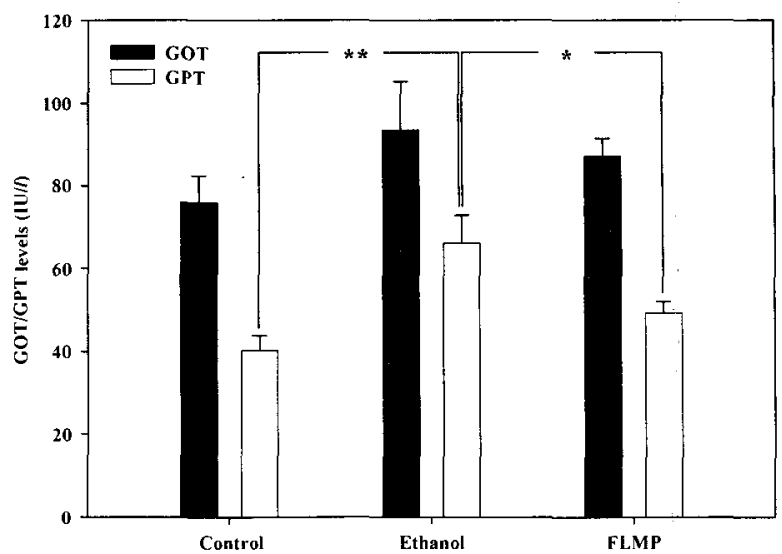

Fig. 3. Effects of ethanol and FLMP on the serum GOT and GPT levels. Rats were administrated with $14 \%$ ethanol and FLMP (14\% alcohol content) twice a day for 10 days and examined by a blood serum analysis instrument. Values are means \pm SEM of eight animals. ${ }^{*}, P<$ $0.05 ; * *, p<0.005$.

cloudy swelling, hydropic degeneration and inflammatory cells infiltration were markedly increased in the ethanol-administrated rat. But a similar histopathological pattern with PAS reaction showed in rats administrated with FLMP compared with control ones (Fig. 5). The iNOS and COX-2 immunoreaction of hepatocytes, especially in the in flammatory loci, were increased in ethanol-administrated groups compared to control ones. But these immunoreactions were decreased in the rats administrated by FLMP with fewer inflammatory loci (Fig. 6).

\section{Discussion}

Generally, $P$. linteus has been used as a medicinal mushroom for the treatment of inflammatory disease and cancer in Korea. The investigations for the crude extract and chemical constituents of this fungus were also focused on

\section{Con Eth FLMP}

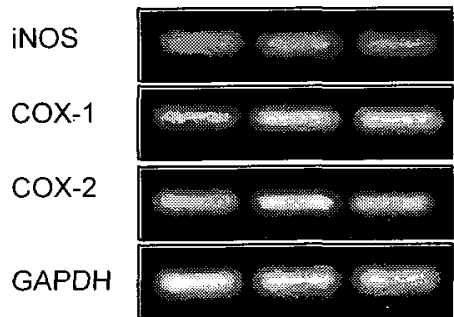

Fig. 4. Effects of ethanol and FLMP on the expression of inflammation-related proteins (A) and mRNA (B) in rat liver. Rats were administrated with 14\% ethanol and FLMP (14\% alcohol content) twice a day for 10 days and examined by Western blot and RT-PCR analysis in rat liver. 

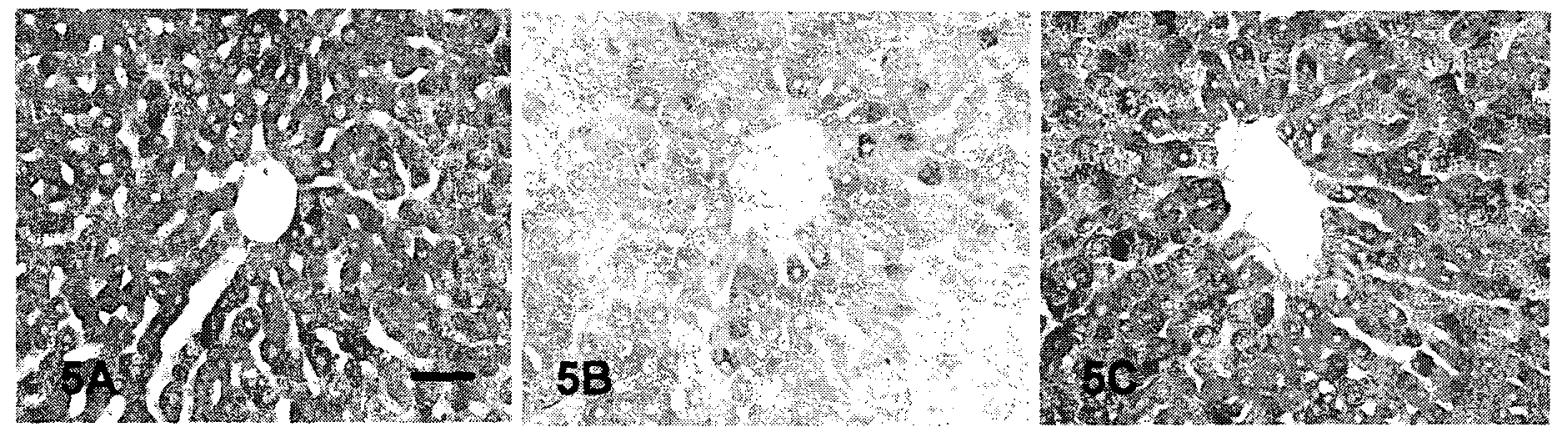

Fig. 5. Photomicrographs showing the liver of the rat in the control (A), ethanol- (B) and FLMP-administrated rats (C). Note severe inflammatory loci and a marked weak PAS reaction of the ethanol-administrated rats compared with the control and FLMP-administrated ones. Scale bar $=50 \mu \mathrm{m}$.
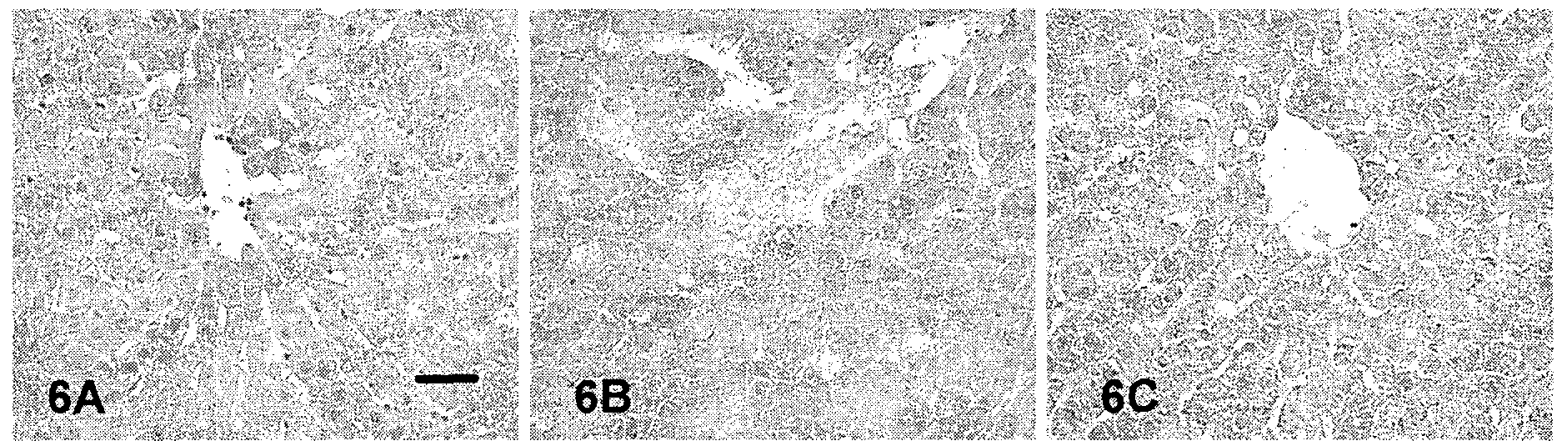

Fig. 6. Immunoreaction of COX-2 in the liver of control (A), ethanol- (B) and FLMP-administrated rats (C). Note decline of COX-2 immunoreaction, especially in inflammatory loci, in the FLMP administrated rats compared with ethanol-administrated ones. Scale bar $=50 \mu \mathrm{m}$.

their anti-tumor activities. Like fruiting bodies of $P$. linteus, its mycelial extract was found to contain potent anti-tumor activities[3] and showed anti-tumor activity toward solid tumors planted in mice[11]. The polysaccharides of mycelial culture of $P$. linteus stimulate humoral and cell-mediated immunity and exhibit a wider range of immunostimulation and anti-tumor activity[5].

The liver is one of the major organs to be damaged during the heavy intake of alcohol. Many studies have demonstrated that liver disease resulted from the dose-and time-dependent consumption of alcohol[4,8]. We have firstly observed that the effects of FLMP on the morphological change of $\mathrm{HepG}_{2}$ cells in the present study. HepG 2 cells treated with FLMP showed a similar morphology as like the normal cells. These results suggest that FLMP may have some components to protect cellular morphology or structure from its own alcohol.

The liver injury in response to alcohol is associated with an inflammatory response as an important precursor to the development of irreversible liver disease[10]. The iNOS is a member of the nitric oxide synthases family and hepatic injury is associated with up-regulation of this enzyme expression $[9,14]$. COX-1 is constitutively expressed in most cells and tissues, whereas COX-2 is only expressed when induced by inflammatory stimuli[16,17]. COX-2 is selectively expressed in response to various inflammatory stimuli and is increased in adjacent cirrhotic tissue of hepatocellular carcinoma[2,12].

In the present study, higher expression of iNOS, COX-1 and COX-2 were induced in the ethanol treated $\mathrm{HepG}_{2}$ cells compared with FLMP-treated cells (Fig. 2). Furthermore, in vivo experimental data confirmed that FLMP could affect an expression of inflammatory proteins in rat liver (Fig. 4). The immunohistochemical analysis also showed a similar result with mRNA and protein expression. The declines of iNOS and COX-2 immunoreaction with a decrease of inflammatory loci in an FLMP-administrated rat were observed compared to ethanol-administrated ones (Fig. 6).

The GOT and GPT levels are correlated with the degree of inflammation or cell death of the liver[7,15]. Therefore, it was investigated that the effects of FLMP on the alteration of GOT and GPT levels in rat blood serum served as 
a liver functional marker. Lower levels of these enzymes, especially GPT, were demonstrated in the serum of FLMP-administrated rats compared to ethanol-administrated ones with histological changes such as fewer inflammatory loci (Figs. 3 and 5).

Previous studies showed that the methanolic extract of the mycelial culture of $P$. linteus significantly protects against hepatotoxins-induced toxicity in primary cultured rat hepatocytes[6]. It suggested that alcohol causes liver damage through hapatocytic necrosis including inflammatory process, but some components of FLMP may prevent alcohol-induced liver injury.

Although exact components of this beverages are not clear, active fraction of FLMP was composed of $68 \pm 9 \%$ of protein and $15 \pm 4 \%$ of sugar. It's constitute of sugars were Glu:Gal:Man:Fru=46.6:12.8:26.4:3.8 in molar ratio. The ${ }^{1} \mathrm{H}$, ${ }^{13} \mathrm{C}-\mathrm{NMR}$ analysis showed that the main glucan part of the extract of FLMP was a mixtures a-D-glucan and $\beta$-D-glucan (unpublished data). Though FLMP has relative low alcohol content (14\%), FLMP can also cause the alcoholic liver disease. However, FLMP administration induced lower expression of inflammation-related proteins in both $\mathrm{HepG}_{2}$ cell and rat liver compared with ethanol. Furthermore, FLMP-administrated groups showed slight changes on the liver enzyme abnormalities. This was also confirmed by histopathological and immunohistochemical observations in rat liver.

As shown in a previous report that anti-tumor polysaccharides from mushrooms are $\beta$-D-glucan[11], the polysaccharides of FLMP may prevent alcohol-induced liver injuries. Consequently, these results suggest that FLMP may have some components to hepatoprotective activities. Then these data will be a useful additional source of information about mycelium of $P$. linteus and a good guide for the developments of the other functional alcoholic beverages.

\section{Acknowledgement}

This Study was supported by Technology Development Program of the Ministry of Agriculture and Forestry, Republic of Korea

\section{References}

1. Araki, H., Y. Komoike, M. Matsumoto, A. Tanaka and K.
Takeuchi. 2004. Healing of duodenal ulcers is not impaired by indomethacin or rofecoxib, the selective COX-2 inhibitor, in rats. Digestion 66, 145-153.

2. Cheng, J., H. Imanishi, H. Iijima, S. Shimomura, T. Yamamoto, Y. Amuro, A. Kubota and T. Hada. 2002. Expression of cyclooxygenase 2 and cytosolic phospholipase $A_{2}$ in the liver tissue of patients with chronic hepatitis and liver cirrhosis. Hepatology Res. 23, 185-195.

3. Choi, Y. H., M. K. Huh, C. H. Ryu, B. T. Choi and Y. K. Jeong. 2004. Induction of apoptotic cell death by mycelium extracts of Phellinus linteusin human neuroblastoma cells. Int. J. Mol. Med. 14, 227-232.

4. Dai, L. L., J. P. Gong, G. Q. Zuo, C. X. Wu, Y. J. Shi, X. H. Li, Y. Peng, W. Deng, S. W. Li and C. A. Liu. 2003. Synthesis of endotoxin receptor CD14 protein in Kupffer cells and its role in alcohol-induced liver disease. World J. Gastroenterol. 9, 622-626.

5. Han, S. B., C. W. Lee, Y. J. Jeon, N. D. Hong, I. D. Yoo, K. H. Yang and H. M. Kim. 1999. The inhibitory effect of polysaccharides isolated from Phellinus linteus on tumor growth and metastasis. Immunopharmacol 41, 157-164.

6. Kim, S. H., H. S. Lee, S. Lee, J. Cho, K. Ze, J. Sung and Y. C. Kim. 2004. Mycelial culture of Phellinus linteus protects primary cultured rat hepatocytes against hepatotoxins. J. Ethnopharmacol. 95, 367-372.

7. Kim, S., C. Y. Hwang, N. K. Kim, M. C. Park and J. Kim. 2002. Effects of cordyceps militaris on $\mathrm{CCl}_{4}$-induced liver damage and cancer cell $\left(\mathrm{HepG}_{2}\right.$ cell) growth. Kor. J. Oriental. Physol. Pathol. 16, 684-692.

8. Mann, R. E., R. G. Smart and R. Govoni. 2003. The epidemiology of alcoholic liver disease. Alcohol Res. Health. 27, 209-219.

9. McNaughton, L., L. Puttagunta, M. A. Martinez-Cuesta, N. Kneteman, I. Mayers, R. Moqbel, Q. Hamid and M. W. Radomski. 2002. Distribution of nitric oxide synthase in normal and cirrhotic human liver. Proc. Natl. Acad. Sci. USA 99, 17161-17166.

10. Nagy, L. E. 2004. Molecular aspects of alcohol metabolism: transcription factors involved in early ethanol-induced liver injury. Annu. Rev. Nutr. 24, 55-78.

11. Nakamura, T., S. Matsugo, Y. Uzuka, S. Matsuo and H. Kawagishi. 2004. Fractionation and anti-tumor activity of the mycelia of liquid-cultured Phellinus linteus. Biosci. Biotechmol. Biochem. 68, 868-872.

12. Qiu, D. K., X. Ma, Y. S. Peng and X. Y. Chen. 2002. Significance of cyclooxygenase-2 expression in human primary hepatocellular carcinoma. World J. Gastroentetol. 8, 815-817.

13. Querol, A., M. T. Fernandez-Espinar, M. del Olmo and E. Barrio. 2003. Adaptive evolution of wine yeast. Int. J. Food. Microbiol. 86, 3-10.

14. Ronco, M. T., L. Alvarez Mde, J. A. Monti, M. C. Carrillo, G. B. Pisani, M. C. Lugano and C. E. Carnovale. 2004. Role of nitric oxide increase on induced programmed cell death during early stages of rat liver regeneration. Biochem. Biophys. Acta 6, 70-76. 
15. Takeda, Y., A. Ichihara, H. Tanioka and H. Inove. 1964. The biochemistry of enzyme from dispersed rat liver cell. J. Biol. Chem. 239, 3590-3596.

16. Warner, T. D and J. A. Mitchell. 2004. Cyclooxygenases: new forms, new inhibitors, and lessons from the clinic.
FASEB J. 18, 790-804.

17. Zha, S., V. Yegnasubramanian, W. G. Nelson, W. B. Isaacs and A. M. De Marzo. 2004. Cyclooxygenases in cancer: progress and perspective. Cancer Lett. 215, 1-20.

\section{초록 : 상황버섯 균사체를 이용한 발효주가 인체간암세포와 흰쥐 간의 염증관련 단백질 발현에 미치는 영향}

안성민 · 이준혁 · 최영현 ${ }^{1} \cdot$ 이용태 ${ }^{2} \cdot$ 정경태 $^{3} \cdot$ 정영기 ${ }^{3} \cdot$ 조운복 $^{4} \cdot$ 최병태 $^{*}$

(동의대학교 한의 과대학 해부학교실, ${ }^{1}$ 생화학교실, ${ }^{2}$ 생리학교실, 자연과학대학 ${ }^{3}$ 생명응용과학과, ${ }^{4}$ 부산대 학교 사범대학 생물교육과)

상황버섯균사체를 이용한 발효주 (FMLP)가 인체간암세포와 흰쥐 간에서 염증관련단백질의 발현과 간 손상 관련효소에 미치는 영향에 대해 조사하였다. 에탄올, FLMP를 인체 간암세포인 $\mathrm{HepG}_{2}$ 세포에 24시간 처리한 경 우, 대조군에 비해 에탄올을 처리한 세포는 농도가 증가할수록 세포의 형태 변화가 심한 반면 FLMP를 처리한 세포는 알코올의 농도가 증가해도 세포의 형태 변화를 관찰할 수 없었다. $\mathrm{HepG}_{2}$ 세포의 염증 관련 단백질 발현을 보기 위해 Western blot과 RT-PCR을 한 결과 COX-1, COX-2, iNOS, TNF- $a$ 의 발현이 에탄올에 의해 현저하게 유도되었으나, FLMP는 $\mathrm{HepG}_{2}$ 세포에서 $\mathrm{mRNA}$ 와 단백질의 발현이 에탄올에 비해 억제되었다. 흰쥐를 이용한 동 물실험에서 간 기능의 지표가 되는 혈청내 GOT와 GPT양 등이 에탄올 투여 그릅에서 현저히 증가했으나 FLMP 를 투여한 그륩에서 에탄올 투여 그룹에 비해 낮게 나타났다. 면역조직화학적 분석에서 에탄올을 투여한 쥐의 간세포에서 $\mathrm{iNOS}$ 와 COX-2의 발현이 현저히 증가하나 FLMP를 투여한 쥐의 간세포에서 미약한 면역반응이 관찰 되었다. 이상의 결과로 보아 FLMP는 동일한 농도의 에탄올에 비하여 간 손상의 가능성이 적은 것으로 사료되며 이 자료들은 상황버섯에 대한 연구와 다른 기능성 주류에 대한 기초 자료가 될 것이다. 